\title{
HLA-DMB Gene
}

National Cancer Institute

\section{Source}

National Cancer Institute. HLA-DMB Gene. NCI Thesaurus. Code C150054.

This gene is involved in the post-translational modification of class II major histocompatibility protein complexes. 